\title{
Evaluation of the Inhibition of Angiotensin-converting Enzyme by New Thiomorpholine Compounds Using Capillary Zone Electrophoresis
}

\author{
Víctor H. Vázquez-Valadez*1, Ivonne Carrillo C. ${ }^{1}$, Nayeli Ramírez C. ${ }^{3}$, Ana María Velázquez-S. ${ }^{2}$, \\ Víctor H. Abrego ${ }^{3}$, Rafael López Castañares ${ }^{4}$, E. Angeles ${ }^{1}$ \\ ${ }^{1}$ Laboratorio de Química Medicinal. Departamento de Ciencias Químicas. Facultad de Estudios Superiores \\ Cuautitlán. Universidad Nacional Autónoma de México, CP 54750. \\ ${ }^{2}$ Laboratorio de Investigación, Nave 3000. Departamento de Ciencias Químicas. Facultad de Estudios \\ Superiores Cuautitlán. Universidad Nacional Autónoma de México CP 54750. \\ ${ }^{3}$ QSAR Analytics S.A. de C.V. Témpano 10, Colonia Atlanta, Cuautitlán Izcalli Estado de México CP 54744. \\ ${ }^{4}$ Facultad de Química, Universidad Autónoma del Estado de México, Cerro de Coatepec s/n, Ciudad \\ universitaria, 50110 Toluca de Lerdo, Méx.
}

* Corresponding author: M.S. Víctor Hugo Vázquez-Valadez, Universidad Nacional Autónoma de México
Laboratorio de Química Medicinal, Ave. 1o de Mayo s/n, Santa María las Torres, 54740 Cuautitlán Izcalli,
Estado de México. Tel: +01-55-56-23-20-66; Fax: +01-55-56-23-20-66; e-mail: hugounam83@me.com

Received January $16^{\text {th }}, 2018$; Accepted June $13^{\text {th }}, 2018$.

DOI: http://dx.doi.org/10.29356/jmcs.v62i3.453

\begin{abstract}
The inhibition capacity of the angiotensin converting enzyme (ACE) was determined by 5 different methylthiomorpholine compounds: (4-tert-butyl-2-(thiomorpholin-4-ylmethyl)phenol (LQM318), 4-tertbutyl-2,6-bis(thiomorpholin-4-ylmethyl)phenol (LQM319), 3,5-bis(thiomorpholin-4-ylmethyl) pyrogallol (LQM322), 4-methoxy-2-thiomorpholin-4-ylmethyl-1-phenol (LQM328) and 3,6-bis(thiomorpholin-4ylmethyl)benzene-1,2-diol (LQM329), using Captopril as a reference. This last drug is used as an antihypertensive agent and known for its biological effect over ACE. The study was done using the capillary electrophoresis technique, with an in-line reaction using hippuryl-histidyl-leucine (HHL) as substrate to produce hippuric acid (HA). HA was detected at $254 \mathrm{~nm}$, which is the detection wavelength to get the quantification of this compound. That was performed under the experimental conditions reported for such interaction. From this, the electrophoretic mobility of hippuric acid was computed in order to deduce the effective migration time and the recovered quantity, to prove and quantify the in-line activity of the enzyme.

Keywords: Angiotensin Converting Enzyme; Capillary Zone Electrophoresis; Captopril; Hippuric Acid; Inhibition.

Resumen. La capacidad de inhibición de la enzima convertidora de angiotensina (ACE) se determinó mediante 5 compuestos diferentes derivados de la metiltiomorfolina: (4-terc-butil-2- (tiomorfolin-4-ilmetil) fenol (LQM318), 4-tert-butil-2,6-bis ( tiomorfolin-4-ilmetil) fenol (LQM319), 3,5-bis (tiomorfolin-4-ilmetil) pirogalol (LQM322), 4-metoxi-2-tiomorfolin-4-ilmetil-1-fenol (LQM328), 3,6 -bis (tiomorfolin-4-ilmetil) benceno-1,2-diol (LQM329) usando como referencia al Captopril. Este fármaco es utilizado como agente antihipertensivo y conocido por su efecto biológico sobre la ACE. El estudio se realizó utilizando la técnica de electroforesis capilar, con una reacción en línea utilizando hippuril-histidil-leucina (HHL) como sustrato para producir ácido hipúrico (HA). El HA se detectó a $254 \mathrm{~nm}$, que es la longitud de onda de detección para obtener la cuantificación de este compuesto. Eso se realizó bajo las condiciones experimentales reportadas para tal interacción. A partir de esto, se calculó la movilidad electroforética del ácido hipúrico para deducir el tiempo efectivo de migración y la cantidad recuperada, esto para probar y cuantificar la actividad en línea de la enzima.
\end{abstract}


Palabras clave: Enzima Convertidora de Angiotensina; Electroforesis capilar de zona; Captopril; Ácido hipúrico; Inhibición.

\section{Introduction}

ACE is a protein of the peptidases chloride-dependent family which makes the catalysis of dipeptides liberation from the C-terminal extreme of its substrate, the angiotensin I [1]. The ACE's role is to carry out the regulation of blood pressure and it is involved in the conversion of decapeptide, Angiotensin I, into octapeptide Angiotensin II, this last compound possesses the maximum vasopressor capacity. Also, ACE makes the inactivation of Bradykinin vasodilator [2] both processes provoke as a consequence the increase of the blood pressure.

It has been reported that the increase of activity of the ACE at a serum level can produce different pathologies as sarcoidosis [3], in which the levels of the enzyme in blood serum are a very stable indicator for the diagnosis of the sarcoidosis disease [2]. Currently, there are different drugs for hypertension and congestive heart failure treatment $[4,5]$.

It is evident that is necessary to search for an accurate inhibitor due to the clinical relevance of the ACE activity. Different techniques have been applied, to reach that objective, such as spectrophotometry[6, 7], fluorometry[8] or radioisotopic [9, 10] methods, besides some theoretical studies have been carried out to predict the possible interaction of new compounds and compare them with the ones already available in the market [11]. The methods of separation and quantification through HPLC started to be developed because of the complicated separation of hippuric acid through the extraction with dissolvent; added to this the separation could not be performed completely [12-14]. Nowadays, different methods have been applied using Capillary Electrophoresis (CE) to separate the HA from the enzymatic reaction between hippuryl histidyl leucine (HHA) and ACE; and to quantify the obtained products with more accuracy. [15-17].

The quantification of ACE activity by capillary zone electrophoresis has been reported [3], and the in-line reaction conditions are well established, where ACE activity is quantified using HHL as tripeptide substrate [2]. In this reaction, the ACE releases Histidyl-Leucine (HL) and Hippuric Acid (HA); this last compound is easily detected with a UV detector at $254 \mathrm{~nm}$.

The CE is a very powerful analytical tool that is able to do separations with an adequate resolution short analysis time and using small sample volumes (usually $\mu \mathrm{L}$ ).

The systems of CE have been applied in a very successful way for in-line enzymatic reactions through a methodology known as electrophoretically mediated microanalysis, also known as EMMA [18]. EMMA takes advantage of all the different electrophoretic mobilities of a protein, the substrate and the product for quantification using an in-line reaction. This technology has been used in different biochemical systems [19-27].

To perform the methodology described by S. Van Dyck, the enzymatic reactions were carried out inline. A stand by time of interaction was necessary in order to perform the reaction and subsequently, voltage was applied to separate and quantify the products of the reaction. The variable in respect to an EMMA analysis is that the enzyme and the substrate are not mixed before the injection to the separation system. The in-line technique described by Taga et al. [28], who made the CE with a derivatization of the reactions inside the capillary using amino acids as model compounds.

On the other hand, in 1985 Stout and his collaborators conducted studies of a natural product known as changroline [29], a substance that showed to have an antiarrhythmic and hypotension effect. In order to determinate which region of the molecule is the responsible for the biological effect, they divided the molecule into three zones, concluding that region 2 is the one responsible of the pursued biological activity (Fig. 1) [30-31].

Considering Stout's work, our group purposed to change the pyrrolidine ring and used the morpholine and thiomorpholine systems instead. In 2007 we synthetized and characterized a group of compounds derived from phenol, named LQM300 [32]. 


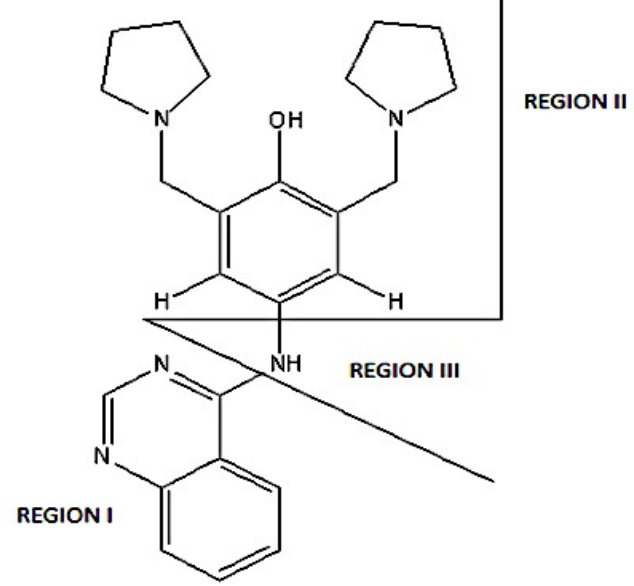

Fig 1. Studied regions by Stout and his collaborators of changroline.

These new compounds were tested in rat model [33], from which the compounds(4-tert-butyl-2(thiomorpholin-4-ylmethyl)phenol (LQM318) 4-tert-butyl-2,6-bis(thiomorpholin-4-ylmethyl)phenol (LQM319), 3,5-bis(thiomorpholin-4-ylmethyl) pyrogallol (LQM322), 4-methoxy-2-thiomorpholin-4ylmethyl-1-phenol (LQM328),3,6-bis(thiomorpholin-4-ylmethyl)benzene-1,2-diol (LQM329) (Fig. 2), were the best candidates from a series of 25 tested molecules. The computational studies previously described [11] indicated a similarity of its biological activity with Captopril and its inhibition is known to act at the level of the ACE, this group of compounds were protected through a patent [33].

A way to determine the level of inhibition is to use the methodology described by S. Van Dyck, et al. [24] where the initial conditions for the analysis were stablished. Also using the computational studies reported results we made the comparative study with the ACE activity using the HHL substrate through the Capillary Zone Electrophoresis (CZE), using Captopril as a positive blank.<smiles>CC(C)(C)c1ccc(O)c(CN2CCSCC2)c1</smiles>

LQM318<smiles>COc1ccc(O)c(CN2CCSCC2)c1</smiles>

LQM328

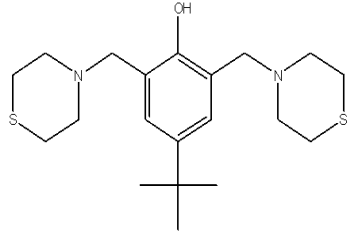

LQM319

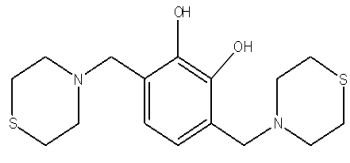

LQM329<smiles>Oc1c(CN2CCSCC2)cc(CN2CCSCC2)c(O)c1O</smiles>

LQM322

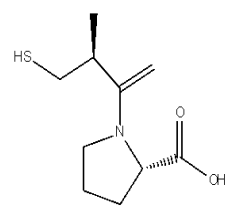

Captorpil

Fig 2. Structure of the compounds; LQM 318, LQM 319, LQM, LQM 328, LQM 329, and Captopril. 


\section{Experimental}

\section{Chemistry}

The LQM300 compounds were obtained and characterized as it is mentioned at reference [32].

\section{Instrumentation of CE}

All the experiments were made in a CE equipment (Beckman Coulter, ProteomeLab PA 800, Fullerton, CA, USA). The detection was made in line with $254 \mathrm{~nm}$ with a diodes arrangement detection system. The migration time and the area under the curve (AUC) were collected and analyzed through the P/A800 MDQ software (version 1.5). The capillary used was made of fused silica (Polymicro Technologies, Phoenix AZ, USA) of $30 \mathrm{~cm}$ long ( $20 \mathrm{~cm}$ from the injection place to the detector) and an internal diameter of $75 \mu \mathrm{m}$.

\section{CE Conditions and solutions}

The reagents such as HHL, HA, ACE, Captropril, $\mathrm{NaCl}$ and HEPES buffer, which were used during the experimentation, were obtained through Sigma-Aldrich. The capillary temperature was regulated at $37^{\circ} \mathrm{C}$ with a cooling liquid during all the experiments.

Type 1 water was used for the preparation of all the solutions and the washing procedure of capillary. Before the solutions were loaded in the CE equipment, they were passed through a $0.45 \mu \mathrm{m}$ nylon filter (Alltech, Lokeren, Belgium) except the ACE solution. A new capillary was used and treated previously with $\mathrm{NaOH} 0.1 \mathrm{M}$, type 1 water and running buffer, each treatment lasted 20 minutes.

The running buffer consists of a $150 \mathrm{mM}$ HEPES (4-(2-hydroxyethyl)-piperazine-1-ethanesulfonic acid) solution, (Sigma-Aldrich, USA) adjusted to $\mathrm{pH} 8.0$ with $0.1 \mathrm{M} \mathrm{NaOH}$ (BDH, Poole, UK). At the beginning of each day the capillary was conditioned through a washing cycle at $20 \mathrm{psi}$, starting with $0.1 \mathrm{M}$ $\mathrm{NaOH}$ for 15 minutes, then 15 minutes with water and 20 minutes with the running buffer.

Previous to each reaction mixture analysis, the capillary was washed with $0.1 \mathrm{M} \mathrm{NaOH}$ and with water for 2 minutes each one besides using a washing procedure of 3 minutes with the running buffer.

During each step of the injection of substrate or the enzyme, the final part of the capillary (and the electrode) were immersed into the buffer with the objective to prevent the system from returning because of the syphon effect.

The HHL, HA and ACE of rabbit lung with $0.1 \mathrm{U}$ of activity were obtained from Sigma-Aldrich (USA). The HHL and ACE were dissolved and prepared with $10 \mathrm{mM}$ (pH 8.0) HEPES buffer and $150 \mathrm{mM}$ of

$\mathrm{NaCl}$. The HA for the calibration curve was dissolved in water type 1 . The compounds and the solutions of ACE and the HHL were kept at $4{ }^{\circ} \mathrm{C}$ and before using them, they were set rest so that they reached room temperature.

\section{Calibration curve of $\mathrm{HA}$ at different concentrations}

The stock solution of the HA at $6.25 \mathrm{mM}$ was prepared dissolving the $\mathrm{HA}$ in a $\mathrm{H}_{2} \mathrm{O} / \mathrm{DMSO}$ (Dimethyl sulfoxide from Sigma Aldrich USA) 50:50. This mixture was used due to the low solubility of the LQM compounds. However, this solution has to be used during the calibration procedure in order to have the same matrix for every system. There were five systems, series of HA solutions into different concentrations, were prepared from the same stock solution in the $10 \mathrm{mM}(\mathrm{pH}=8.0)$, HEPES buffer, containing $150 \mathrm{mM}$ $\mathrm{NaCl}$, The curve goes through a concentration range of 0.1 to $0.55 \mathrm{mM}$, where the system 1 was the most diluted system and system 5 was the most concentrated HA solution. Each system was analyzed three times at $254 \mathrm{~nm}$. Each HA migration time was used to evaluate the precision of the method and the AUC was also analyzed in order to obtain an equation to compute the HA concentration.

\section{In-line Reaction}

Sandwich injections were carried out for the enzyme-substrate reaction. Before and after the sandwich injections cycle, water was injected ( $0.3 \mathrm{psi}, 3 \mathrm{~s})$, enzyme ( $3 \mathrm{psi}, 5$ seconds each) and substrate ( 3 psi, 5 seconds). A period of waiting time for 10 minutes was set to perform the reaction inside the capillary and later a separation voltage of $6 \mathrm{kV}$ was applied. The steps of the method applied for the procedure of washing, injection and reaction conditions are showed in table 1 . 
Table 1. The procedure of the in-line reaction and capillary conditions. The temperature of the capillary was regulated at $37^{\circ} \mathrm{C}$ with antifreeze liquid during the entirety of the analysis. Each analysis was carried out three times.

\begin{tabular}{|c|c|c|c|c}
\hline Action & Solution & Presure (psi) & Voltage (kV) & Time \\
\hline \multirow{4}{*}{ Washing } & NaOH & 20 & - & $2 \mathrm{~min}$ \\
\cline { 2 - 5 } & Water & 20 & - & $2 \mathrm{~min}$ \\
\cline { 2 - 5 } & Buffer & 20 & - & $2 \mathrm{~min}$ \\
\hline \multirow{4}{*}{ Injections } & Water & 0.3 & - & $3 \mathrm{~s}$ \\
\cline { 2 - 5 } & Enzyme & 0.3 & - & $5 \mathrm{~s}$ \\
\cline { 2 - 5 } & $\begin{array}{c}\text { Substrate- } \\
\text { inhibitor }\end{array}$ & 0.3 & - & $5 \mathrm{~s}$ \\
\cline { 2 - 5 } & Enzime & 0.3 & - & $5 \mathrm{~s}$ \\
\cline { 2 - 5 } & Water & 0.3 & - & $3 \mathrm{~s}$ \\
\hline Waiting time & - & - & - & $10 \mathrm{~min}$ \\
\hline \multirow{3}{*}{$\begin{array}{c}\text { Separation and } \\
\text { quantification }\end{array}$} & - & - & 6 & $15 \mathrm{~min}$
\end{tabular}

HHL was used as a substrate with a concentration of $1 \mathrm{mM}$ each mixed with $39.5 \mathrm{mM}$ of inhibitors. A stock solution was prepared, dissolving HHL with $10 \mathrm{mM}, \mathrm{pH} 8.0$ of HEPES buffer and $150 \mathrm{mM} \mathrm{NaCl}$. Captopril and the LQM300's compounds were used as inhibitors, which were dissolved in a $\mathrm{H}_{2} \mathrm{O} / \mathrm{DMSO}$ (50:50) mixture. Each substrate/inhibitor solution was diluted with $10 \mathrm{mM}, \mathrm{pH} 8.0$ of HEPES buffer and was analyzed three times.

\section{Results and discussion}

\section{In-line reaction through capillary electrophoresis.}

Five LQM compounds were selected (Fig. 2) to determine the inhibitor effect upon the ACE with respect to the HHL with the procedure reported previously [3]. To improve the detection of the HA a 10 min waiting time was applied. This will lead to a higher concentration of HA.

The injection order and conditions are shown in Table 1. The substrate plug can either contain or not contain the inhibitor compound in order to observe its effect. This has the advantage that by adding the compound to that plug, it will not cause an inhibition until the mixture is completed. On the other hand the order of the injection of each component in the capillary is aimed to guaranty that the evaluated compounds react as a whole at the same time.

\section{Calibration Curve of HA}

In order to determine the ACE inhibition, the HA must be quantified. The calibration curve was measured as described in the experimental section 2.4. However, for the statistical part for the calibration curve the corrected migration time was not used.

Due to the low solubility of the inhibitors in water, they were dissolved in a 50:50 water / DMSO mixture. It should be mentioned that under these conditions the mixture is stable only on the same day so it must be prepared fresh.

The statistical analysis was made based on the migration time of HA and the AUC for each one of the measurements (Table 2), proving that the results are statistically precise for the migration time measurement (V.C. $=2.8 \%$ ) and for the AUC with a coefficient percentage of a maximum variation of $6.5 \%$ (Fig. 3 and Fig. 4). The parameter measured was the migration time, this was in order to identify the HA and to verify that the method is reproducible. 


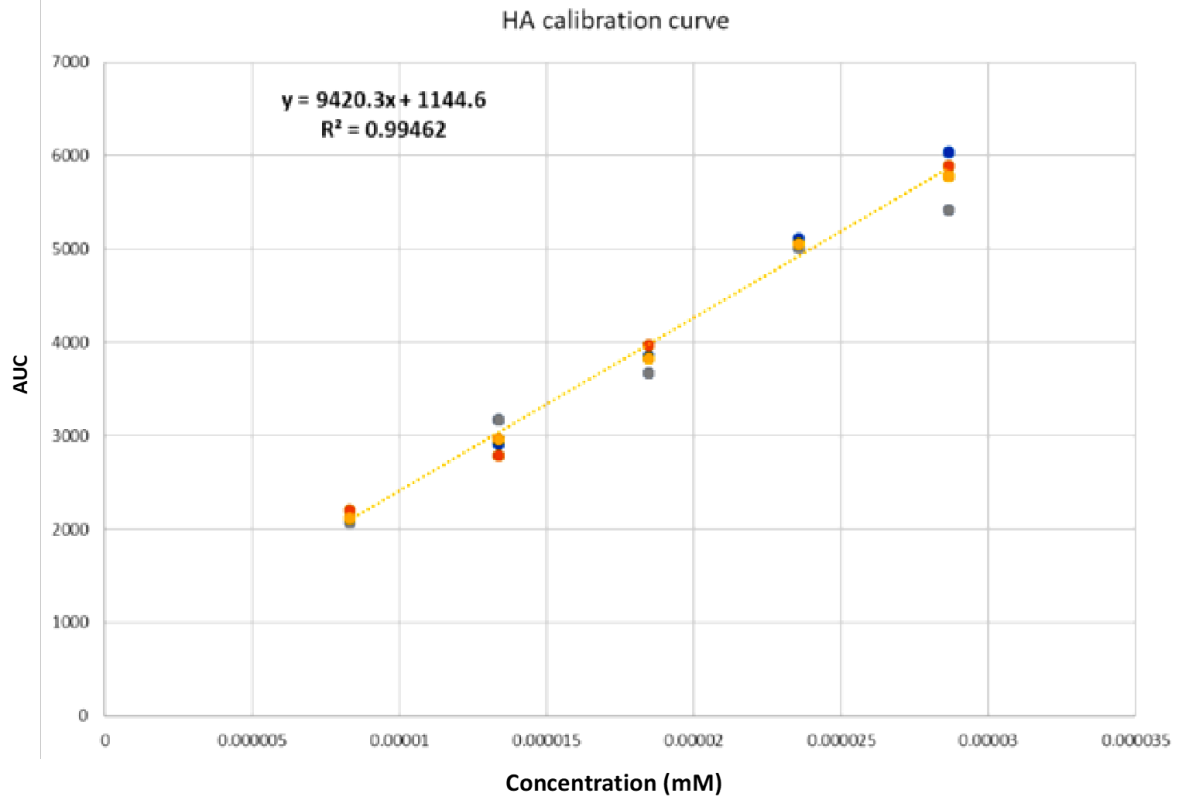

Fig 3. Data dispersion from the calibration curve (concentration $m M$ vs AUC). The plot shows the measurements and the average of the AUC (yellow dots). Also the equation is showed and the final correlation coefficient of this process was: $\mathrm{r}^{2}=0.994$.

Table 2.- Statistical analysis from the migration time and the AUC for each system. SD stands for standard deviation, CV stands for coefficient of variance; both of them are for AUC and for HA migration time measurements.

\begin{tabular}{|c|c|c|c|c|c}
\hline & System 5 & System 4 & System 3 & System 2 & System 1 \\
\hline AUC & 5802 & 5076 & 3856 & 2980 & 2140 \\
\hline SD & 321 & 47 & 150 & 195 & 72 \\
\hline CV & $\mathbf{0 . 0 5 5}$ & 0.009 & $\mathbf{0 . 0 3 9}$ & 0.065 & 0.034 \\
\hline $\begin{array}{c}\text { Average HA } \\
\text { migration } \\
\text { time }\end{array}$ & 7.95 & 7.8 & 7.84 & 7.99 & 7.79 \\
\hline $\begin{array}{c}\text { SD for HA } \\
\text { migration } \\
\text { time }\end{array}$ & 0.32 & 0.14 & 0.18 & 0.33 & 0.15 \\
\hline $\begin{array}{c}\text { CV for HA } \\
\text { migration } \\
\text { time }\end{array}$ & $\mathbf{0 . 0 4 0}$ & $\mathbf{0 . 0 1 8}$ & $\mathbf{0 . 0 2 3}$ & $\mathbf{0 . 0 4 1}$ & $\mathbf{0 . 0 1 9}$ \\
\hline
\end{tabular}




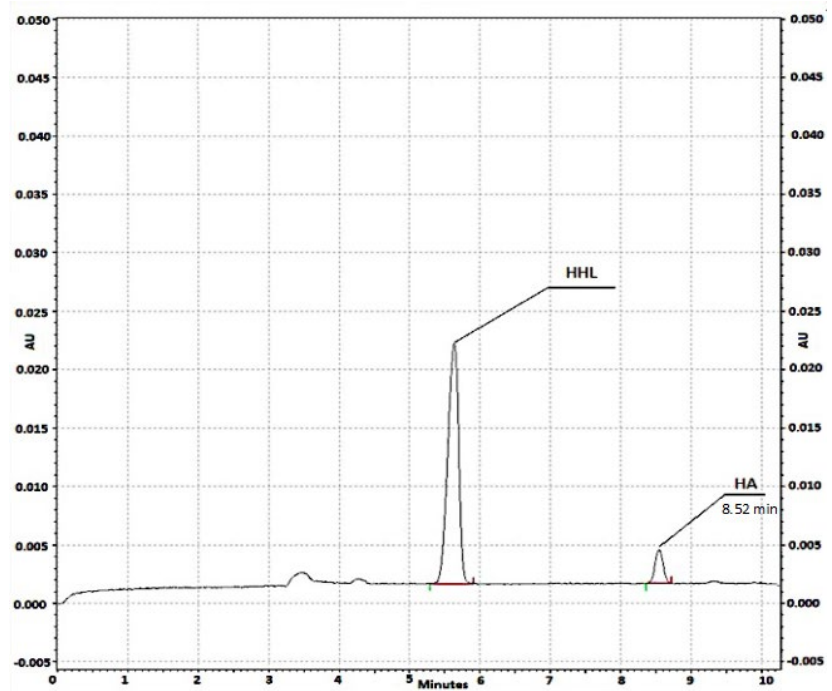

Fig 4. Typical electropherogram obtained after on-line reaction at the capillary inlet, without any inhibitor added to the substrate plug. The concentration of ACE: $0.1 \mathrm{U} / \mathrm{ml}$, HHL: $1 \mathrm{mM}$, HA: $0.78 \mathrm{mM}$. Waiting period

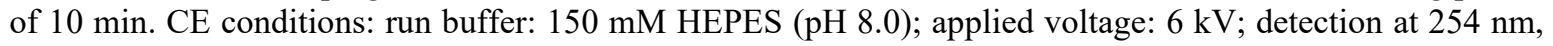
capillary cartridge temperature: $37^{\circ} \mathrm{C}$.

\section{Comparison of different inhibitors}

To determine the inhibition of the ACE with the different LQM compounds the procedure described in section 2.4 was performed three times for each one of the compounds, including Captopril and using the reaction without inhibitor as a reference, for $100 \%$ of the reaction product. In order to compute the HA concentration, the equation from the calibration curve was used. Making the interpolation with the mentioned equation, we can get the HA concentration directly from the AUC readings, and applied to the inhibition percentage equation.

The inhibition percentage of each compound was calculated through the expression:

$$
\% \text { Inhibition }=100-\frac{[H A]}{\text { Blank }} * 100
$$

The blank refers to the HA concentration in the reaction with no inhibitor, in our case was $0.78 \mathrm{mM}$ and the analysis of results is shown in table 3. Where the total inhibition stands for each compound level of inhibition compared to the solution without any inhibitor. And the relative inhibition is measured compared with the Captopril level of inhibition, which for this study was taken as the $100 \%$. The LQM322 compound has the second higher inhibition activity (Fig. 5), with almost $80 \%$ of inhibition, although this compound is the best of the new proposed compounds, it is still under the inhibition percentage of Captopril (Fig. 6).

Table 3. Total inhibition percentage (average) of ACE and relative inhibition regarding Captopril. The migration time presented in this table is the corrected migration time.

\begin{tabular}{|c|c|c|c|}
\hline Inhibitor & $\begin{array}{c}\text { tm } \mathbf{~ H A} / \mathbf{H}_{2} \mathbf{O} \\
(\mathbf{m i n})\end{array}$ & $\begin{array}{c}\text { \% Total } \\
\text { Inhibition }\end{array}$ & $\begin{array}{c}\text { \% Relative } \\
\text { Inhibition }\end{array}$ \\
\hline 318 & 2.3 & 26.5 & 28.9 \\
\hline 319 & 2.3 & 29.3 & 31.8 \\
\hline 322 & 2.5 & 80 & 86.8 \\
\hline 328 & 2.5 & 34 & 36.6 \\
\hline 329 & 2.4 & 4.7 & 5.1 \\
\hline Captopril & 2.8 & 92.1 & 100 \\
\hline Without inhibitor & 2.6 & Not detected & Not detected
\end{tabular}




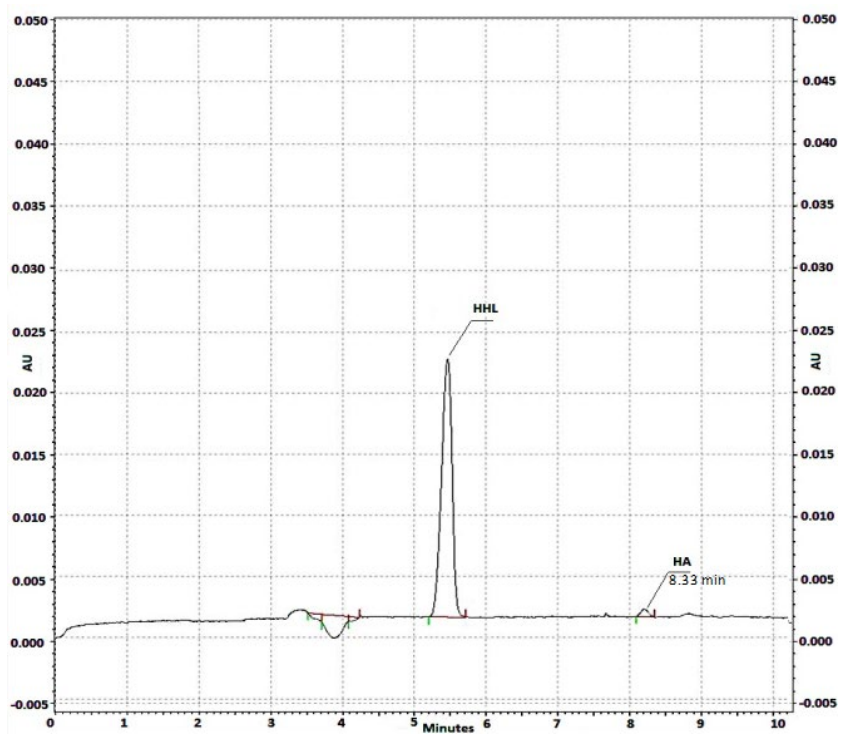

Fig 5. Electropherogram obtained after on-line reaction at the capillary inlet, with LQM 322 compound added to the substrate plug. The concentration of ACE: $0.1 \mathrm{U} / \mathrm{ml}$, initial HHL: $1 \mathrm{mM}$ concentration. HA: $0.23 \mathrm{mM}$. Waiting period of $10 \mathrm{~min}$. CE conditions: run buffer: $150 \mathrm{mM}$ HEPES (pH 8.0); applied voltage: $6 \mathrm{kV}$; detection at $254 \mathrm{~nm}$, capillary cartridge temperature: $37^{\circ} \mathrm{C}$.

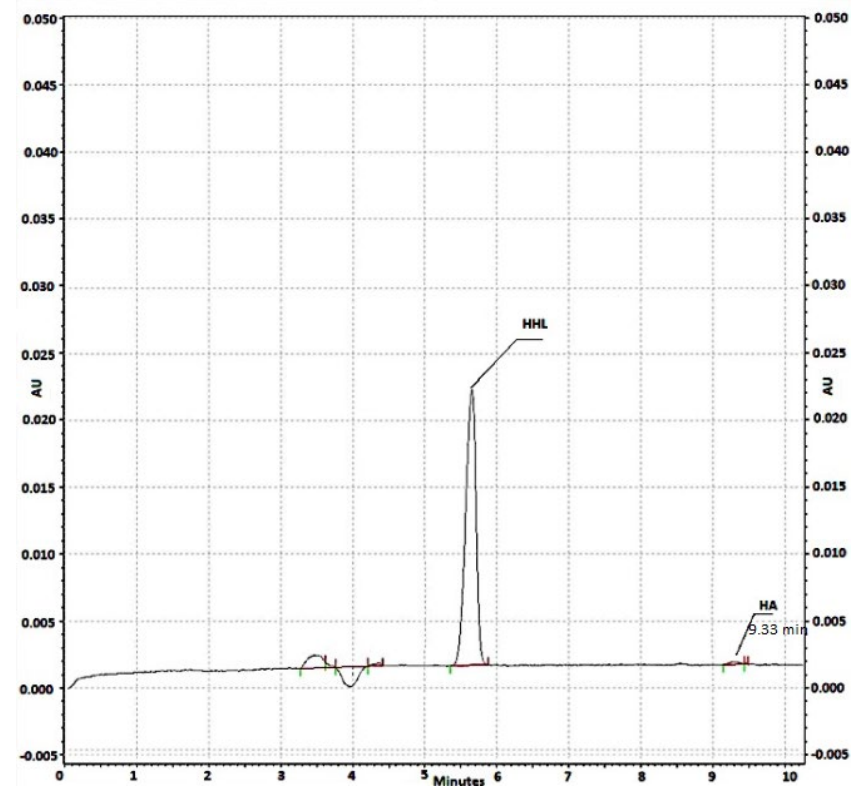

Fig 6. Electropherogram obtained after on-line reaction at the capillary inlet, with Captopril compound added to the substrate plug. The concentration of ACE: $0.1 \mathrm{U} / \mathrm{ml}$, initial HHL: $1 \mathrm{mM}$ concentration. HA: $0.058 \mathrm{mM}$. Waiting period of $10 \mathrm{~min}$. CE conditions: run buffer: $150 \mathrm{mM}$ HEPES (pH 8.0); applied voltage: $6 \mathrm{kV}$; detection at $254 \mathrm{~nm}$, capillary cartridge temperature: $37^{\circ} \mathrm{C}$.

\section{Electrophoretic Mobility}

Electro-osmosis, as well as electro migration, is an electro-kinetic phenomenon that happens when an potential difference is applied to a fluid system in direct contact with a charged surface, like in the CE, and this is called electroosmotic flow (EOF). 
This expression is used to correct migration apparent time:

$$
t_{i}=\frac{L_{T^{2}}}{\left(\mu_{e}+\mu_{e o}\right) * V}
$$

where, $\mathrm{t}_{\mathrm{i}}$ effective or real migration time of compound $\mathrm{i}(\mathrm{s}) ; \mathrm{L}_{\mathrm{T}}$ : total length of the capillary separation $(\mathrm{cm})$; $\mu_{\mathrm{e}}$ compound i mobility only for electro migration $\left(\mathrm{v} / \mathrm{E}=\mathrm{cm} 2 / \mathrm{V}^{*} \mathrm{~s}\right) ; \mu_{\mathrm{eo}}$ : electroosmotic mobility and $\mathrm{V}$ : applied voltage.

As observed in equation 2, effective migration time depends on the mobility of the solute and the EOF. To identify EOF in an electropherogram, it is necessary to add a marker, a neutral substance which moves at the same speed as the EOF, as the EOF, therefore, the negative peak of the water (due to its lower absorption compared with the buffer) was used as a neutral marker.

The electrophoretic mobilities are calculated through the following equations:

$$
\begin{aligned}
& \mu_{e}=\frac{L_{D^{*} L_{T}}}{V * t_{m}} \\
& \mu_{e o}=\frac{L_{D} * L_{T}}{V * t_{e o}}
\end{aligned}
$$

where; $\mathrm{L}_{\mathrm{D}}$ : capillary length until the detector $(\mathrm{cm}) ; \mathrm{t}_{\mathrm{m}}$ : migration time $(\mathrm{s})$ and $\mathrm{t}_{\mathrm{eo}}$ : migration time of the electroosmotic flow (s).

The analysis of results is shown in table 4 where effective mobilities of EOF and HA obtained with Ec. 2 and 3 are show in Table 3. The effective migration times are shown to give an idea of the precision on the identification of the HA peaks.

Table 4. Electroosmotic and HA mobilities and the effective migration time of HA.

\begin{tabular}{|c|c|c|c|c|}
\hline & \multicolumn{2}{|c|}{ Mobility (cm $\left.{ }^{2} \boldsymbol{N}^{\star} \mathbf{s e g}\right)$} & \multicolumn{2}{c|}{$\begin{array}{c}\text { Effective migation } \\
\text { time of the HA }\end{array}$} \\
\hline Inhibitor & OEF & HA & (s) & (min) \\
\hline 318 & $5.06 \times 10^{-4}$ & $2.29 \times 10^{-4}$ & 204 & 3.4 \\
\hline 319 & $4.33 \times 10^{-4}$ & $1.89 \times 10^{-4}$ & 241 & 4 \\
\hline 322 & $4.85 \times 10^{-4}$ & $2.02 \times 10^{-4}$ & 218 & 3.6 \\
\hline 328 & $5.26 \times 10^{-4}$ & $2.32 \times 10^{-4}$ & 198 & 3.3 \\
\hline 329 & $4.95 \times 10^{-4}$ & $2.14 \times 10^{-4}$ & 212 & 3.5 \\
\hline Captopril & $4.76 \times 10^{-4}$ & $1.79 \times 10^{-4}$ & 229 & 3.8 \\
\hline $\begin{array}{c}\text { Without } \\
\text { Inhibitor }\end{array}$ & $4.93 \times 10^{-4}$ & $1.98 \times 10^{-4}$ & 217 & 3.6 \\
\hline Average & $4.88 \times 10^{-4}$ & $2.06 \times 10^{-4}$ & 216 & 3.6 \\
\hline
\end{tabular}

Although each of the LQM compounds possess a lower inhibition compared to Captopril, we can find molecular similarities inside the studied compounds. By analyzing table 3 the percentage of relative inhibition to Captopril, it is observed that the LQM322 compound possess an inhibition close to Captopril because LQM322 compound presents an $86 \%$ of relative inhibitory effectivity. On the other hand, the other compounds showed a relative inhibition that was significantly lower, swinging between $5 \%$ and $36 \%$. Suggesting that it is not only necessary to have a bis-substituted structure, but the position of these substitutes will also directly impact the activity and its inhibition power. This allows to determine a chemical structure as a head of series to develop a compound which biological activity could be benefited. The LQM322 compound was the compound that presented the major activity, $86.8 \%$ in comparison with Captopril. Aside from its chemical structure, it could also be a compound with antioxidant activity. It was determined that the 
compounds to be active facing the $\mathrm{ACE}$, require two thiomorpholine rings at the 4 and 6 relative positions, and that having polyphenols at position 1,2 and 3 increase the inhibition activity. The LQM329 also have two tiomorpholine rings and two hydroxyl groups, however this compound does not have those substituents at the same positions, this slight modification drastically modify the biological activity. This behavior could be labeled as an activity cliff.

The information reported in the patent derived from the synthesis and the in vivo rat studies [33], describes the compounds as substances that have a cardio protective and antiarrhythmic activity. It has also been found in this patent, that the dose of LQM compounds is less than that dose in the Captopril.

\section{Concluding remarks}

The performance and precision of the in-line reaction of the ACE and its HHL substrate through CZE was achieved. The calibration curve was performed for the quantification of HA (product of the reaction) to determine the inhibiton power of the studied compounds, using Captopril as a reference.

Through the CE method, it is confirmed that the compounds of the LQM300 series act on a level of inhibitors of the ACE being the LQM322 compound (3,5-bis(thiomorpholin-4-ylmethyl)pyrogallol) the most active inhibitor with an $86.8 \%$ percentage of effectivity compared with Captopril, while the less active is LQM320 with an activity of $5.1 \%$ in comparison to Captopril. This allow us to have a closer understanding of the necessary molecular characteristics for the design of a compound that allows to inhibit this enzyme. Suggesting that not only it is necessary to have a bis-substituted structure, but also that the position of the bissubstitued structure will directly impact the activity and its inhibitor power. Finally, it was determined that the compounds, in order to be active in front of the ACE, require two thiomorpholine rings and a phenol nucleus, allowing to confirm the inhibition activity of the LQM300 series of compounds with the ACE, which is according with previous computational studies reported.

\section{Acknowledgments}

We would like to thank, D. Jiménez, M. Hernández from FESC-UNAM and for their skillful technical assistance, CONACyT for the scholarship received during the present study since Victor Hugo Vazquez Valadez is a doctoral student from Programa de Doctorado en Ciencias Biomédicas, Universidad Nacional Autónoma de México UNAM. Proyect: PAPIIT IT200817, PAPIIT No 202015, Cátedra PIAPI1607: Diseño de moléculas bioactivas and for the translation service to Mildred Angelica Sauce Guevara.

\section{References}

1. White, J.S., White, D.C., (Eds.), Source Book of Enzymes, CRC Press, New York, 1997, p. 516-528.

2. Beneteau-Burnat, B., Baudin, B. Crit. Rev. Clin. Lab. Sci. 1991, 28, 337-357.

3. Lieberman, J., Rea, T.H., Ann. Intern. Med. 1977, 87, 422-425. DOI 10.7326/0003-4819-87-4-422

4. Cushman, D.W., Ondetti, M.A., Biochem. Pharmacol.1980, 29, 1871-1877 DOI: 10.1016/00062952(80)90096-9

5. Bünning, P., J. Card. Pharmacol. 1987, 10, S28-S31.

6. Cushman, D.W., Cheung, H.S., Biochem. Pharmacol. 1971, 20, 1637-1648. DOI:10.1016/00062952(71)90292-9

7. Schnaith, E., Beyrau, R., Bückner, B., Klein, R.M., Rick, W., Clin. Chim. Acta 227 1994, 145-158 DOI: 10.1016/0009-8981(94)90143-0

8. Friedland, J., Silverstein, E., Am. J. Clin. Pathol. 1976, 66, 416-424. DOI:10.1093/ajcp/66.2.416 
9. Ryan, J.W., Chung, A., Ammons, C., Carlton, M.L., A simple radioassay for angiotensin-converting enzyme Biochem. J. 1977, 167, 501-504. DOI:10.1042/bj1670501

10. Ryder, K.W., Thompson, H., Smith, D., Sample, M., Sample, R.B., Oei, T.O., Clin. Biochem. 1984, 17, 302-305. DOI:10.1016/S0009-9120(84)90601-5

11. Vázquez-Valadez, V. H., Abrego, V.H., Martínez, P.A., Torres, G., Zúñiga, O., Escutia, D., Vilchis, R., Velázquez, A.M., Martínez, L., Ruiz, M., Camacho, B., López-Castañares, R., Angeles, E., Open Med Chem J. 2013, 7, 30-38. DOI:10.2174/1874104501307010030

12. Chiknas, S.G., Clin. Chem. 1979, 25, 1259-1262.[PubMed]

13. Neels, H.M., Scharpe, S.L., Van Sande, M.E., Verkerk, R.M., Van Acker, K.J., Clin. Chem. 1982, 28, 1352-1355.

14. Meng, Q.C., Balcells, E., Dell'italia, D., Durand, D., Oparil, S., Biochem. Pharmacol, 1995, 50, 14451450. DOI:10.1016/0006-2952(95)02038-1

15. Van Dyck S, Vissers S, Van Schepdael A, Hoogmartens J Chromatogr A. 2003 Feb 7;986(2):303-311. DOI:10.1016/S0021-9673(02)01995-7

16. Shihabi, Z.K., J. Chromatogr. 1999, A 853, 185-188. DOI:10.1016/S0021-9673(99)00474-4

17. Zhang, R.Z., Xu, X.H., Chen, T.B., Li, L., Rao, P.F., Anal. Biochem. 2000, 280, 286-290. DOI:10.1006/abio.2000.4535

18. Bao, J., Regnier, F.E., J. Chromatogr. 1992, 608, 217-224. DOI:10.1016/0021-9673(92)87127-T

19. Miller, K.J., Leesong, I.K., Bao, J.M., Regnier, F.E., Lytle, F.E., Anal. Chem. 65 (1993) 3267-3270. DOI: $10.1021 / \mathrm{ac} 00070 \mathrm{a} 017$

20. Wu, D., Regnier, F.E., Linhares, M.C., J. Chromatogr. 1994, B 657, 357-363. DOI:10.1016/03784347(94)00140-5

21. Bao, J.J., Fujima, J.M., Danielson, N.D., J. Chromatogr. 1997, B 699, 481-497. DOI:10.1016/S03784347(96)00244-7

22. Watanabe, T., Yamamoto, A., Nagai, S., Terabe, S., Electrophoresis 1998, 19, 2331-2337. DOI:10.1002/elps.1150191313

23. Saevels, J., Van Schepdael, A., Hoogmartens, J., Electrophoresis 1996, 17, 1222-1227. DOI:10.1002/elps.1150170709

24. Van Dyck, A., Van Schepdael, A., Hoogmartens, J., Electrophoresis 2001, 22, 1436-1442. 10.1002/1522-2683(200105)22:7<1436::AID-ELPS1436>3.0.CO;2-8

25. Van Dyck, S., Van Schepdael, A., Hoogmartens, J., Electrophoresis 2002, 23, 2854-2859. https://doi.org/10.1002/1522-2683(200209)23:17<2854::AID-ELPS2854>3.0.CO;2-Y

26. Saevels, J., Van den Steen, K., Van Schepdael, A., Hoogmartens, J., J. Chromatogr. 1996, A 745, $293-$ 298.

27. Whisnant, A.R., Johnston, S.E., Gilman, S.D., Electrophoresis 2000, 21, 1341-1348. https://doi.org/10.1002/(SICI)1522-2683(20000401)21:7<1341::AID-ELPS1341>3.0.CO;2-9

28. Taga, A., Honda, S., J. Chromatogr. 1996, A 742, 243-250. DOI:10.1016/0021-9673(96)00250-6

29. Stout, D. M., Matier, W. L., Barcelon,Y.C., Reynolds, R. D., Brown, B. S. J. Med. Chem. 1983 26, 808 - 813. DOI: 10.1021/jm00360a005

30. Stout, D. M., Matier, W. L., Barcelon,Y.C., Reynolds, R. D., Brown, B. S. J. Med. Chem. 1984 27, 1347 - 1350. DOI: $10.1021 / \mathrm{jm} 00376 \mathrm{a} 022$

31. Stout, D. M., Matier, W. L., Barcelon,Y.C., Reynolds, R. D., Brown, B. S. 1985 J. Med. Chem. 28(3), 295-298. DOI: 10.1021/jm00381a006

32. Velázquez, A. Ma., Torres, L. A., Díaz, G., Ramírez, A., Hernández, R., Santillán, H., Martínez, L., Martínez, I., Díaz-Barriga, S., Ábrego, V., Balboa, M. A., Camacho, B., López Castañares, R., DueñasGonzález, A., Cabrera, G., Angeles, E. Arkivok. 2006, ii, 150-161. DOI:10.3998/ark.5550190.0007.218

33. Martinez Aguilar, L., Velazquez Sanchez, A.M., Diaz-Barriga Arceo, S., Romero Rojas, A., Posada Galarza, M.E.R., Angeles, E., (Universidad Nacional Autonoma de Mexico, Mex.). Mex. Pat. Appl. (2007), CODEN: MXXXA3 MX 2005PA12635 A 20070522. Application: MX 2005-12635 20051123 Title 2986332012. 